\title{
Structure Transformation of Indonesia Economic Year Period 2000-2014
}

\author{
Tajuddin $^{1}$, Muh. Syarif ${ }^{2}$, M. Natsir ${ }^{3}$, Zainuddin Saenong ${ }^{4}$ \\ ${ }^{1}$ (Doctoral Program of Economic Science, Halu OleoUniversity Kendari, Southeast Sulawesi, Indonesia) \\ ${ }^{2,3,4}$ (Lectures ofHalu Oleo University Kendari, Southeast Sulawesi, Indonesia)
}

\begin{abstract}
This study aims to identify and analyze: (1) The pattern of structure transformation of Indonesia economic according to output (GDP) and employment; and (2) Impact of reduction in the share of the primary sector to the growth of the sector. This study used secondary data such as GDP and employment Year 20002014, published data sourced from various years. This study used descriptive analysis method is the analysis of share and growth analysis. The results showed that: (1) Based on output (GDP) and employment transformation of economic structure Indonesia moves from the primary sector to the tertiary sector then the secondary sector (patterns P-T-S); (2) The decline in the share of the primary sector and the increasing contribution of the tertiary sector either by PDB or employment was not followed by a decline in economic growth in the sector. The patterns of economic structure transformation in Indonesia produce economic structures that are not qualified. Stepping economic growth of the primary sector to the tertiary sector does not provide a high multiplier effect against economy. Suggested the government to formulate a development of upstreamdownstream is a development strategy that strengthens the secondary sector-based Primary and supported by the services sector.
\end{abstract}

Keywords: structure transformation and economic growth

\section{Introduction}

Development is a process of change, which changes the condition of "unfavorable" to condition the "better". The change will have an impact on improving people's income. So the increase in revenue is not the purpose of development, but the increase in revenue is a result of the changes. In the classical theories have led by Adam Smith argued that the strength of invisible hand economic will always move toward equilibrium (full employment). Similarly Todaro (2004: 16) argues that development as a multidimensional process of change

Based on the above, the transformation of the economic structure is part of the development process. The process of changing the economic structure is often also referred to as the process of industrialization. The transformation of the economic structure can occur in the growth and decline, but the transformation of the economic structure of the desired course in a positive direction, which is marked by a shift in the contribution of agriculture to industry and from sector to sector jasa.Hal industry is based on the purpose of economic development ie it should be able to improve the welfare of the people, for the people's welfare was the target of a building, (Saraan S, Ramli, Sharif I, Rujiman. 2010). The theory of economic structure changes concentrate on the economic structure transformation patterns experienced by developing countries that originally subsistent (traditional agriculture) and then to the more modern sectors of the economy that is dominated by non-primary sectors, especially industry and services. There are two main theories that are commonly used to analyze changes in the economic structure of Arthur Lewis (migration theory) and Hollis Chenery (structural transformation theory). The conclusion both theories above are a transformation of the pattern of economic structure traditional subsistence agriculture economy to a more modern, more oriented to urban life, and has a manufacturing sector that is more varied and the services sector are formidable. This conclusion is reinforced by the results of research Yinmei WU, et al (2006) who said that in China since 1950 occurred transformation of economic structure. Industry become a force in development in Changjian. Similarly, Margaret MC Milan (2011), concluded that the change of economic structure in Nigeria where there are two sectors of the economy namely agriculture traditional village (rural) and the modern industrial sector in cities or urban.

In contrast to the results of research Sudarmono (2006), which suggests that the structural transformation occurs only in the District of Semarang and Kendal? Structural transformation that occurs is not followed by a sectoral shift in employment from agriculture to industry in both the District. The results of this study together with the findings Rumbia (2016), that in Sulawesi Tenggara was economic structure changes to the 12 districts / cities in Sulawesi Tenggara. Changes of Pattern in economic structure and employment do not follow the normal pattern. There are several areas where changes in economic structure from the primary sector straight to the tertiary sector.

Based on these descriptions do research with the aim to identify and analyze patterns of change in the economic structure of Indonesia Year 2000-2014. 


\section{Literature Review}

\section{Definition of Economic Structure Transformation}

The theory of economic structure transformation theory also called structure theory to shift the economy. This theory was originally arise from the stream economists classic popularized by Fisher (1939) and Clark (1940). The theory of transformation of economic structure to focus on changes in the production and use of production factors used.

Economic transformation is the process of changing the economic structure characterized by a shift from one economic sector to other economic sectors that may affect changes in the Gross Regional Domestic Product (GDP) or Gross Domestic Product (GDP) in a country or a region. Transformation is a process of gradual change and arrives at the ultimate stage, the changes made by way of response to the influence of external and internal elements that will lead to significant changes from previously known forms through the process repeatedly doubling or multiplying.

Economic Transformation movement of labor from low-productivity sector to sector higher productive activities (eg, from agriculture to manufacturing) and the sector (for example, from subsistence agriculture to high value crops) .It is widely accepted that poverty reduction and growth the economy can not be sustained without economic transformation and change in productivity.

Economic transformation is a dynamic reallocation sourced from less productive sectors to more productive sectors. The transformation of the economic structure is generally defined as a process in which an increase in the proportion of economic output and employment generated by sectors other than agriculture. This transformation process connotes a shift from agriculture-based society to an urban, industrial or service-based economy with a sustained high GDP growth rates. GDP growth combined with a reduction in population growth rate resulting from increased access to quality education and the increase in GDP per capita, which in turn reduces poverty.

\section{Pattern Transformation of Economic Structure}

Chenery (1975) explains that the process of transformation of economic structure will reach the level that was faster when the shifting pattern of domestic demand towards the industrial output of manufacturing reinforced by a similar change in the composition of trade or export as occurred in the group of countries Newly Industrialized Countries (NICs), Furthermore Sukirno (2007: 202) argues that the theory Fei-Ranis and Lewis on the process of economic development explained concepts related to transfer of the agricultural sector to industrial sector labor.

Lewis in Todaro (2006: 68) explains that the economy of developing countries consists of two main sectors, namely agriculture of subsistence and the modern sector (industry and services). The agricultural sector is a sector of the rural population abundance so too abundant labor (surplus of labor). This condition is technically indicated by marginal productivity is equal to zero. With so movement of workers from agriculture to other sectors did not affect production in the agricultural sector. The main emphasis of this theory is the process of movement of workers from rural agriculture to urban industrial sector as well as an increase in output.

Chenery (1975) in theory Pattern of Development describes structural changes in the stages of the process of economic change from developing countries experiencing the transformation from traditional agriculture to switch to industry sector as a major engine of economic growth. Increasing the role of the industrial sector in the economy in line with the increase in per capita income are strongly associated with the accumulation of capital and increased resources (Human Capital).

When viewed from the side of labor, there will be the movement of workers from the rural agriculture sector to the urban industrial sector, although the shift is still lagging (lag) than structural change process itself. In the presence of this lag, the agricultural sector will play an important role in increasing the labor supply, either from the beginning or the end of the transformation of the structural changes.

Fisher in International Labour Riview in 1935 suggested that various countries can be distinguished based on the percentage of workers who work in the primary sector, secondary and tertiary. Clark in his study showed that the higher the per capita income of a country, the smaller the role of agriculture in providing employment opportunities. Instead the industrial sector increasingly large role in providing employment, (Sukirno, 2007: 144)

Fisher supported by Clark (1940) put forward the theory of the shifting patterns of economic structure. This theory focuses on the changes in the production and use of production factors used in the hypothesis that there will be changes in the value of production and the use of labor with the development of an economy. Fisher (1935) suggests that economic growth is accompanied by a shift in demand from the primary sector to the secondary sector and finally to the tertiary sector. This resulted in a change in the structure of production through the shift of employment opportunities and the allocation of funds. Clark (1940, 1951, 1957), suggests that there is a close relationship between changes in the structure of production and employment opportunities 
by sector. Clark has also approached the economic development process in terms of economic structure changes, called Stage of Development Theory (theory stage of development). This theory is strengthened and supported by Simon Kuznets $(1957,1958)$ states that the contribution of the various sectors of the change in the national production creates a measurable change in the economic structure.

\section{Economic growth}

According to Adam Smith (1776) growth process begins when the economy is able to carry out the division of labor would increase productivity, which in turn will increase revenue. After Adam Smith, emerged thoughts that examines growth boundaries (limits to growth), among others Malthus (1798) and Ricardo (1917) referred to a classical flow. Then, developing modern theory of economic growth with the importance of capital accumulation (physical capital formation) and improving the quality of human resources (human capital). One of the major impacts of development and continues today is the growth model developed by Harrod (1948) and Domar (1946) at the core of this model rests on the premise Keynes (1936), which emphasizes the importance of demand in driving long-term growth.

Ailenei, et al. (2011) and Blakely (1989) involves the cognitive dimension of economic growth. Development must be thought of as a multidimensional process involving major changes in the social structure, people's attitudes and in institutions - national institutions, with the pursuit of accelerated economic growth, reduction of inequality and poverty eradication. Under these conditions, a benchmark of success of development can be seen from the economic growth, economic structure and smaller income inequality among the population, between regions and between sectors.

The same thing according to Sukirno (2006: 423) that economic growth is an increase in the ability of an economy to produce goods and services. Economic growth showed the extent to which economic activity would generate additional income of the people in a given period. Economic growth is defined as "a process that causes the per capita income of a resident of a community to rise in the long term".

In the book An Inquiry into the Nature and Causes of the Wealth of Nations (1776) Adam Smith argued prosesp economic rowth in the long run systematically. In order for economic growth process easier to understand, we distinguish two main aspects, namely economic growth of total output growth and population growth.

The key elements of the production system of a country according to Smith, there are three, namely: (1) natural resources; provided (or factor of production "land"); (2) human resources (or total population); and (3) the stock of capital goods. According to Smith, the natural resources available are the most fundamental factor in production activities. The amount of natural resources available is the "maximum limit" for the growth of an economy. That is, if these resources have not been used fully, the population and the stock of existing capital that plays a role in the growth of output growth output. But will stop if all of those resources have been used in full.

Human resources (number of people) has a passive role in the growth process output. That is, the population will adapt to the needs of a employee society. Capital stock, according to Smith, is element of production which actively determines the output level. The amount and rate of output growth depends on the growth rate of the capital stock (up to "maximum limit" of natural resources).

\section{Conceptual Framework}

Development as a process, therefore the construction is dynamic. Development moved in tandem with the human effort to meet their needs. The dynamics and development process that framework of the transformation of economic structure in regional and national scale.

Lewis in theory "model of two sectors" says that in developing countries occur transformation of economic structure of economic pattern subsistence agriculture traditional to an economy that is more modern, more oriented to urban life, and has a manufacturing sector that is more varied and the services sector are formidable (Todaro, 2004: 133). The theory is supported by Yingmei Lewis, et al (2006) that since 1950 China has been a transformation in the structure of the economy through changes in land use. Industrialization has become the most powerful forces of change in the development Changjian. Almost all of the resources earmarked areas in an effort to modernize the production of industrial and urban development system (industrialization) and urbanization has been a success story.

Chenery (1975) concluded that a transformation of the pattern of economic structure traditional subsistence agriculture economy to a more modern, more oriented to urban life, and has a manufacturing sector that is more varied and the services sector are formidable. This conclusion is reinforced by Margaret MC Milan (2011), concluded that the change of economic structure in Nigeria where there are two sectors of the economy namely agriculture traditional village (rural) and the modern industrial sector in cities or urban.

Several other studies showed different results, namely the transformation of the economic structure moves from the primary sector to sector directly tertiary. Sudarmono (2006), concluded that the structural 
transformation occurs only in the District of Semarang and Kendal. Structural transformation that occurs is not followed by a sector shift in employment from agriculture to industry. Similarly Rumbia (2016), concluded that there has been a change in the structure of the economy to 12 districts / cities in Sulawesi Tenggara. Pattern changes in economic structure and employment do not follow the normal pattern. There are several areas where changes in economic structure from the primary sector straight to the tertiary sector. From these explanations it can be concluded that there are two patterns of economic transformation-the transformation of the primary sector (P) to the secondary sector (S) and then to the tertiary sector (T) (PST pattern) and the transformation of the economic structure with pattern from the primary sector $(\mathrm{P})$ to sector tertiary $(\mathrm{T})$ and then to the secondary sector (S) or ( PST Pattern). The pattern of economic transformation is described as follows:

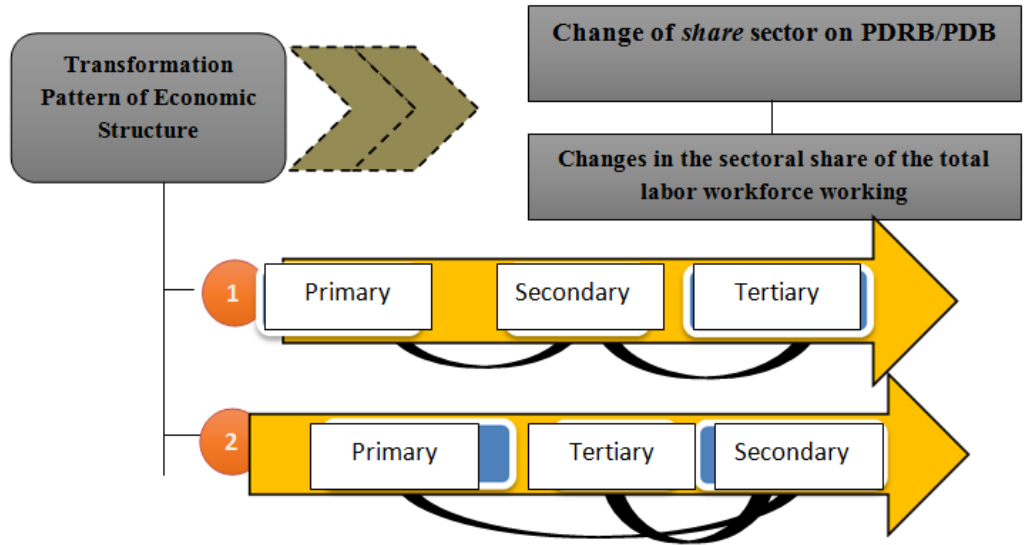

Gambar 1. Transformation Patern of Economic Structure

\section{Data types}

\section{Methodology}

This study uses secondary data. The data is sourced from the Central Bureau Statitik and other official documents. The types of data needed is PDB based on constant 2000 Year 2000-2014; and the population 15 years and over who work on the main business field in 2000-2014.

Data analysis technique

In accordance with the problems and objectives to be achieved, then this research using descriptive analysis. This method uses a mathematical formulation is:

1) Formulation of the share / proportion. This formula is used to calculate the share of the sector / sub-sector of the economy to GDP / GRDP.

$$
\mathrm{SAE}_{\mathrm{pi}}=\underset{\sum_{i=1}^{n} \mathrm{AE}_{\mathrm{pi}}}{\mathrm{TAE} \mathrm{p}} \mathrm{x} 100
$$

Source: Agustian and Ilham (2008)

$\mathrm{SAE} \mathrm{Pi}=$ share of the sector $/$ sub $\mathrm{Pi}(\%)$, where pi is the primary, secondary and tertiary sector

AE Pi pi = GDP (billion)

TAE $\mathrm{p}=$ Total GDP in $\mathrm{p}$ (billion rupiah)

2) Formulation of growth. This formula is used to calculate the growth of the sector / sub economic sector.

(Sukirno: 2007: 9)

$\mathrm{G}=$ Growth sectors / sub-sectors of the economy

PDB1 = Gross Domestic Product period t (based on constant prices)

PDB0 $=$ Gross Domestic Product period previous period

\section{Result and Discussion}

Since 2000 nominal GDP of Indonesia is dominated by the tertiary sector 557,579.8 billion (41.1\%), secondary sector amounted to $433,902.6(31.9 \%)$ while the primary sector only amounted to $366,691.4$ billion $(27.0 \%)$, This shows that in 2000 Indonesia will no longer be characterized as an agricultural country but has been transformed into a country with the economic dominance of the service sector. Figure 1 below describes a shift in the share of the primary sector to GDP. 
Figure 1 Primary sector share to GDP Over 2000 Constant Prices, Years 2000-2014 (Percent)

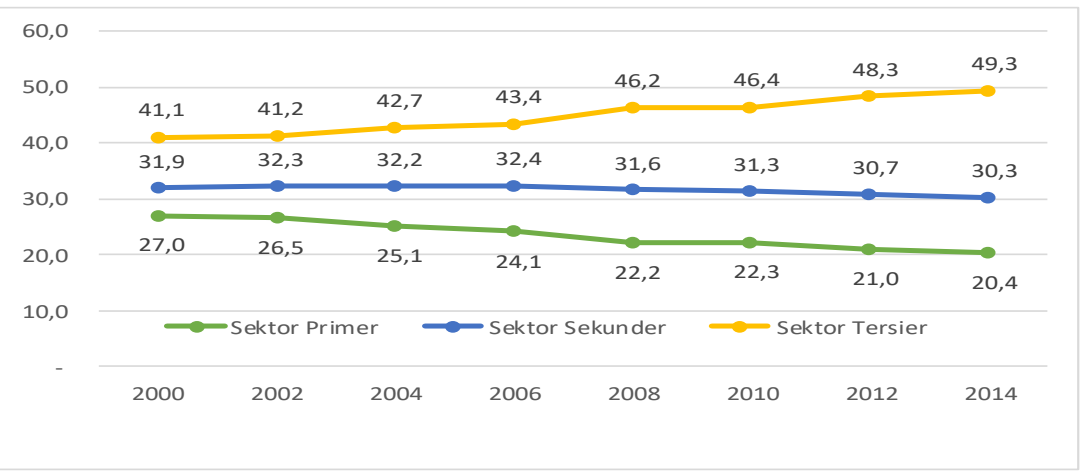

Source: Statistics Indonesia (Year 2000-2015, processed)

In Figure 1 above shows that in the Year 2000 to 2014 decline in the share of the primary sector and increasing the share of the tertiary sector to the GDP. In 2000 the share of primary sector to GDP of 27 percent become down to 26.5 percent in 2002. Similarly, continue to decline until 2014. Instead of tertiary sector to experience are different things that have increased throughout the year from 2000 to 2014 .

Based on the share shift in Indonesia's economic structure in Figure 1 above can be said that the transformation of economic structure is dominated by the tertiary sector (T) then the secondary sector (S) and the last sector of the primary (P). Based on the data it can be concluded that there has been a transformation of the economic structure in Indonesia. The pattern of transformation of economic structure is primary sector to tertiary sector. Search needs to be done since when the role of the primary sector was taken over by the tertiary sector.

Furthermore, in Table 1 below appears that the pattern of Indonesia's economic structure is secondary tertiary--primary pattern (T-S-P) took place since the year 2000. In the year 2000 economic structure consists of the primary sector by 27.0 percent; secondary sector 31.9 percent and the service sector by 41.1 percent. The same pattern occurred until 2014. Descriptions of the Indonesian economy structure pattern described in Table 1 below.

Table 1. Main Sector Role against Gross Domestic Product at Constant 2000 Prices, Years 2000-2014 (Percent)

\begin{tabular}{|c|c|c|c|c|}
\hline \multicolumn{1}{|l|}{ Year } & Primary Sector & Secondary Sector & Tertiary sector & Structure Economic Pattern \\
\hline 2000 & 27,0 & 31,9 & 41,1 & T-S-P \\
\hline 2001 & 26,9 & 32,3 & 40,8 & T-S-P \\
\hline 2002 & 26,5 & 32,3 & 41,2 & T-S-P \\
\hline 2003 & 26,0 & 32,1 & 41,9 & T-S-P \\
\hline 2004 & 25,1 & 32,2 & 42,7 & T-S-P-P \\
\hline 2005 & 24,7 & 32,4 & 42,9 & T-S-P \\
\hline 2006 & 24,1 & 32,4 & 43,4 & T-S-P \\
\hline 2007 & 22,4 & 32,2 & 45,4 & T-S-P \\
\hline 2008 & 22,2 & 31,6 & 46,2 & T-S-P \\
\hline 2009 & 22,9 & 31,5 & 45,6 & T-S-P \\
\hline 2010 & 22,3 & 31,3 & 46,4 & T-S-P \\
\hline 2011 & 21,5 & 31,0 & 47,4 & T-S-P \\
\hline 2012 & 21,0 & 30,7 & 48,3 & T-S-P \\
\hline 2013 & 20,6 & 30,9 & 48,5 & T-S-P \\
\hline 2014 & 20,4 & 30,3 & 49,3 & \\
\hline
\end{tabular}

Source: Statistics Indonesia (Year 2000-2015, processed)

T: tertiary

S: Secondary

P: Primary

Besides contribution of economic sectors to GDP, Indonesia's economic structure transformation can also be seen from the aspect of labor absorption. Figure 2 describes the change in the share of employment in sectors of the economy in the year 2000 to 2014. 
Figure 2 the share shifts Economic Sectors In Labor Force Absorption 2002-204 years (percent)

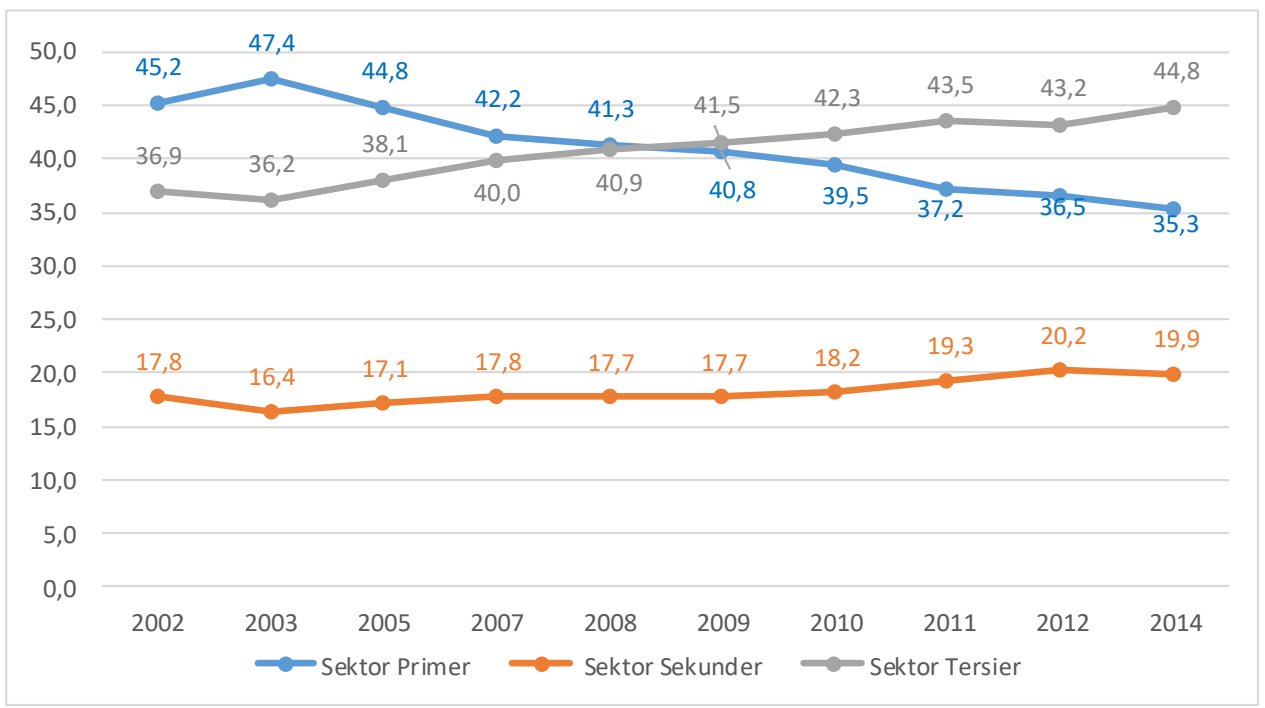

Source: Major Developments Socioeconomic Indicators Indonesia (Year 2000-2015, processed)

In Figure 2 above, we see that the share of primary sector in employment since 2005 has decreased. In 2003 the number of workers absorbed in the primary sector amounted to 47.4 percent down to 44.8 percent at the end of Year 2014.Penurunan share of the primary sector in employeement continued to decline to 35.3 percent in 2014. Despite the decline, but the dominance of the primary sector in employment occurred until 2008.

In the same period in year 2003-2014 increased employment that is consistent in secondary and tertiary sectors. In 2003 as many as 36.2 percent of employeement was absorbed in tertiary sector and 16.4 per cent in secondary sector. The increase in employment in the tertiary sector more consistent also the average percentage increase is greater than the secondary sector. Based on the above phenomenon, it can be concluded that based on aspects of employment since 2003 has transformation of economic structure from the primary sector to the tertiary sector.

If it is connected between the share of the primary sector with a decline in the sector's growth then it appears that the decline in the share of the primary sector does not impact on the growth sectors of economy. Growth by major sectors experienced an increase but unstable and volatile. In 2008, the primary sector grew is negative because of mining sector output decline of 21.6 percent. Economic growth was also slower primary sector compared with other sectors. In 2002 the primary sector grew by 6.53 per cent increase slightly in 2014 to 9.04 per cent.

Table 2. Main Sector GDP Growth Over 2000 Constant Prices Year 2000-2014 (percent)

\begin{tabular}{|c|c|c|c|c|c|c|c|}
\hline Main Sector & 2002 & 2004 & 2006 & 2008 & 2010 & 2012 & 2014 \\
\hline Primary Sector & 6,53 & 2,56 & 8,15 & $(1,72)$ & 18,98 & 6,02 & 9,04 \\
\hline Secondary Sector Sekunder & 9,41 & 8,36 & 13,26 & 4,18 & 17,11 & 10,90 & 10,47 \\
\hline Tertiary Sector & 8,74 & 12,39 & 14,46 & 13,91 & 18,49 & 17,60 & 14,44 \\
\hline
\end{tabular}

Source: Indonesia Statistics (Year 2000-2015, processed)

During the period 2002-2008 the average economic growth in the primary sector by 7.08 percent; 10.53 per cent of the secondary sector and the tertiary sector most is 14.29 percent. The growth of the tertiary sector is not only the highest of the other sectors, but also relatively stable, it can be seen in Figure 3.Grafik tertiary sector was the top show that this sector grows higher than other sectors. Slighter graph shows that the sector is growing more stable. The stability of growth in this sector due to tertiary sector more flexible (adaptive) to changes in economic conditions. One example at the time of the rise of the public rejection of the financial services system of usury, banks crowded crowded open the service with the pattern of sharia. In contrast to the agricultural sector, pasa time perkembunan slump for example cocoa production took a long time to recover. 


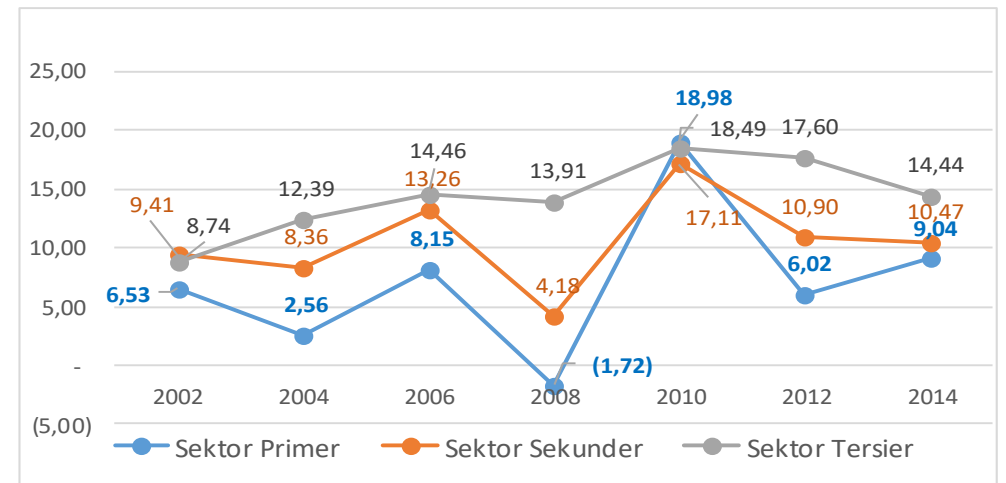

Figure 3. Economic Growth by Sector Top Top Year 2000 Constant Prices 2000-2014 (percent)

The picture above shows that although slower but the primary sector is still experiencing growth. In 2002 the primary sector grew by 6.53 percent, but in 2004 the sector grew only by 2.56 percent but in 2014 the sector grew by 9.04 percent. If connected between decreased share of the primary sector to GDP including its contribution to employment, it can be concluded that the transformation of the economic structure in the form of a decrease in the share of the primary sector in the GDP does not impact on the growth of the sector. Both share decline in GDP and employment is affected by the decline in the competitiveness of secondary and tertiary sectors. Since 2000 Indonesia is no longer an agricultural country, it is characterized by an economic structure that most $(41.1 \%)$ contributed by the tertiary sector; 31.9 percent of the secondary sector and only 27.0 per cent was contributed by the primary sector (Tabe 1). In addition to the contribution that small role in formation of PDB trend also decreased. If in 2000 the primary sector, contributing 27.0 percent, in 2014 decreased to 20.4 percent (Figure 1).

Economic growth structures that occur in Indonesia as a theory Todaro (2004) that the development is "change process". Also the classical theory cecara prove optimistic with hand invesible kekutan economy is always moving towards full employment. Economic transformation Patern in Indonesia is of primary-tertiary pattern then secondary (PTS), it is consistent with the findings (Rumbia: 2016), and Sudarmono (2006 ), but unlike the Chenery in theory pattern of development who see economic development will take place gradually from the primary sector to the secondary and then to tertiary. Sector differs from the pattern of economic transformation Yingmei findings WU, et al (2006), and the theory of Lewis says that in developing countries occur transformation of the economic structure of economic pattern subsistence agriculture and traditional to the economy more modern, more oriented to urban life, and has a manufacturing sector that is more varied and the services sector that is resilient it is also reinforced by the findings Hidayat A and Nazara S (2005), Malunda (2012: 5) den gan case of Rwanda (Africa), and Margaret MC Milan in 2011 with the case of Nigeria.

Chenery theoretical differences with the results of this study due to the assumptions used by Chenery did not fully apply in Indonesia. Theoretical framework Chenery transformation of economic structure stems from the increase in per capita income which would then trigger an increase in demand for goods industry. This assumption is not entirely valid in Indonesia due to the increase in per capita income turns contribution of small percentage of people (owners of capital). Tambunan (2009) argues that although the level of the average income per capita increased rapidly, but if the distribution cripple the revenue increase is not that significant for the growth of industries in addition to industries that make simple items, such as food, beverages, shoes, and apparel (textiles). Demonsrtration influence effect in Indonesia also lead to a high demand for goods-based industrial products greater than the demand for small and medium industrial products. The interesting issue of this study is the transformation of economic structure characterized by a decrease in the contribution of primary sector was not followed by a decline in the growth of the primary sector. Premier sector continued to grow despite a lower growth rate than other sectors. The decline in contribution of primary sector becase of less competitive and lose the productivity aspects of secondary and tertiary sectors.

\section{Conclusion}

Indonesia is no longer an agricultural country, it is characterized by an economic structure which is largely contributed by the tertiary sector is well seen by its contribution to GDP and in employment. Indonesia's economic structure underwent a transformation from the primary sector to the tertiary sector. In addition to its role small contribution to GDP trend also decreased. The decline in the primary sector's contribution to GDP growth was not followed by a decline in the sector. Suggested Indonesian government to establish a pattern of upstream-downstream, consist of concept of development which strengthens the primary sector which is based upon the industry sector and services. It should also do research since when Indonesia switched from the primary sector to the tertiary sector. 


\section{References}

[1] Ailenei Dorel, 2011. Economics of Sustainable Development. Competitiveness and Economic Growth, Theoreticaland Applied Economics Volume XVIII (2011), No.2(555), pp. 5-12

[2] Agustian, A dan Ilham N, 2008. Analisis Proporsi Pendapatan dan Pengeluaran Rumah Tangga Petani Padi Pada Berbagai Ekosistem. Pusat Analisis Sosial Ekonomi dan Kebijakan Pertanian Departemen Pertanian, Bogor (makalah seminar nasional)

[3] Badan Pusat Statistik, (Berbagai terbitan). Statistik Indonesia Tahun 2015, Badan Pusat Statistik Jakarta Indonesia.

[4] Chenery, Hollis B. and Syrquin, Morshe, 1975. Patteren of Development 1950-1970. Washington D.C: The World Bank

[5] Clark, C. (1940). The Condition of Economic Progress. London: Macmillan.

[6] Key-Mu-Yi Jjing Zang, 2011, Perubahan Struktur Pada Perekonomian Terbuka di Michigon.

[7] Kuncoro Mudrajad, 1997. Ekonomi Pembangunan, Teori Masalah dan Kebijakan, UPPAMP YKPN, Yogyakarta

[8] Kuznets, S. (1955), Economic Growth and Income Inequality: American Economic Review 45 : 1-28.

[9] Malunda, Dickson. 2012, Rwanda Case Study On Economic Transformation, Report for the African Centre for Economic Transformation (ACET), Institute of Policy Analysis and Research - Rwanda (IPAR)

[10] Mpango, Philip, 2015, Transformasi Sosial Ekonomi untuk Penanggulangan Kemiskinan: Delapan Pesan Untuk Membuka Potensi Tanzania, http://www.repoa.or.tz/documents/REPOA_BRIEF_37.pdf

[11] Rumbia, Wali, 2015. Analisis Perubahan Struktur Ekonomi dan Struktur Penyerapan Tenaga Kerja Dalam Perekonomian Provinsi Sulawesi Tenggara, Universitas Halu Oleo Kendari, 2015

[12] Saraan S, Ramli, Syarif I, Rujiman. 2010. Analisis Transformasi Struktural Ekonomi Di Indonesia, Jurnal Mepa Ekonomi.

[13] Sukirno, Sadono, 2007. Ekonomi Pembangunan, Masalah dan dasar Kebijakan, edisi kedua, kencana Jakarta.

[14] Sudarmono, Mulyanto. 2006. Analisis Transformasi Struktural, Pertumbuhan Ekonomi dan Ketimpangan Antar Daerah di Wilayah Pembangunan I Jawa Tengah, , Universitas Diponegoro.

[15] Todaro, M.P, 1995., Economic Development, Fifth Edition, Longman, New York \& London

[16] Yingmei WU, et, al. 2006. Economic Structure Transformation and Land Use Change of the Changjiang River Basin, Chinese Geographical Science 2006 16(4), p. 289-293.

[17] WILLEM, DIRK 2015 , TRANSFORMASI EKONOMI ,HTTPS://WWW.ODI.ORG/COMMENT/8084-ECONOMIC-TRANSFORMATION-HEADINGPOST-2015 DI DOWNLOAD 17 OKTOBER 2016 